\title{
PENGARUH KOMPETENSI DAN MOTIVASI KERJA TERHADAP KUALITAS LAYANAN PADA KPKNL PALU
}

\author{
DIAH PEBRIYANTI \\ LINA MAHARDIANA \\ RISNAWATI \\ Jurusan Manajemen, Fakultas Ekonomi, Universitas Tadulako \\ Email: pebriyanti.diah@yahoo.com
}

\begin{abstract}
The purpose of this study are: 1) to determine the influence of competence and work motivation on service quality at KPKNL Palu; 2) to determine the influence of competence on service quality at $K P K N L$ Palu; 3) to determine the influence of work motivation on service quality at KPKNL Palu. Sample consists of 72 people/employees representing their work units. Research method using multiple linear analysis method. The results indicate that $Y=0.068+0.152 X 1+0.839 X 2$. The test shows that competence and work motivation simultaneously have significant influence on service quality. Partial tests show that competence has non-significant influence on service quality while work motivation significantly influence the quality of service. The determinant coefficient shows the value of $R$-Square of 0.904, which means that $90.4 \%$ of service quality are influenced by competence and work motivation, while the rest of $9.6 \%$ is influenced by other variables that are not examined in this study.
\end{abstract}

Keywords: competence, motivation, and service quality.

\section{ABSTRAK}

Tujuan penelitian ini adalah: Untuk mengetahui pengaruh kompetensi dan motivasi kerja terhadap kualitas layanan pada KPKNL Palu. Untuk mengetahui pengaruh kompetensi terhadap kualitas layanan pada KPKNL Palu. Untuk mengetahui pengaruh motivasi kerja terhadap kualitas layanan pada KPKNL Palu. Sampel yang digunakan dalam penelitian berjumlah 72 orang/pegawai yang mewakili satker. Metode penelitian ini menggunakan metode analisis linear berganda. Berdasarkan hasil analisis data, maka persamaan regresi yang di dapat adalah sebagai berikut: $Y=0,068+0,152 X_{1}$ $+0,839 \mathrm{X}_{2}$. Hasil pengujian hipotesis pertama bahwa variabel kompetensi dan motivasi kerja secara serempak berpengaruh signifikan terhadap kualitas layanan. Kemudian pada uji parsial menunjukkan variabel kompetensi berpengaruh tidak signifikan terhadap kualitas layanan dan variabel motivasi kerja berpengaruh signifikan terhadap kualitas layanan. Koefisien determinasi memperlihatkan nilai $R$ Square sebesar 0,904 yang menunjukkan bahwa 90,4\% variabel kualitas layanan dipengaruhi oleh variabel kompetensi dan motivasi kerja, sedangkan sisanya sebesar 9,6\% dipengaruhi oleh variabel lain yang tidak diteliti dalam penelitian ini.

Kata Kunci: Kompetensi, Motivasi kerja, Kualitas layanan.

\section{PENDAHULUAN}

Manajemen sumber daya manusia berkaitan dengan pengelolaan manusia melalui aktivitasaktivitas organisasi dan fungsi-fungsi operasionalnya. Bangun (2012:5) mengemukakan manajemen sumber daya manusia sebagai suatu proses perencanaan, pengorganisasian, penyusunan staf, penggerakkan, dan pengawasan terhadap pengadaan, pengembangan, pemberian kompensasi, pengintegrasian, pemeliharaan, dan pemisahan tenaga kerja untuk mencapai tujuan organisasi. Manajemen sumber daya manusia mempunyai tugas untuk mengelola unsur manusia secara baik, agar diperoleh tenaga kerja yang puas akan pekerjaannya.

Kantor Pelayanan Kekayaan Negara dan Lelang (KPKNL) Palu merupakan unit organisasi yang diberi mandat oleh Kantor Pusat Direktorat Jendral Kekayaan Negara (DJKN) untuk mengelola kekayaan negara secara maksimal hal yang perlu dibenahi adalah aset negara yang dikelola oleh satker, untuk membenahi manajemen aset negara menuju terlaksananya tertib administrasi, tertib hukum dan tertib fisik supaya terwujud pengelolaan kekayaan negara yang optimal yang dikelola oleh satuan kerja- satuan kerja (satker) yang berada di wilayah tersebut. Satuan kerja atau biasa disebut 
dengan satker adalah kuasa pengguna anggaran/kuasa pengguna barang yang merupakan bagian dari suatu unit organisasi pada Kementerian Negara/Lembaga yang melaksanakan satu atau beberapa kegiatan dari suatu program. Seperti kegiatan rekonsiliasi, pelaporan dan konsultasi.

Kompetensi pegawai merupakan strategi yang diarahkan untuk meningkatkan kualitas layanan kepada masyarakat. Menurut Spencer dan Spencer dalam Sutrisno (2009:202), kompetensi mendasari karakteristik dari suatu individu yang dihubungkan dengan hasil yang diperoleh dalam suatu pekerjaan. Adapun Siswanto dalam Sartika (2015:55) mendefinisikan kompetensi sebagai kemampuan manusia (yang dapat ditunjukkan dengan karya, pengetahuan, keterampilan, perilaku, sikap, motif atau bakatnya) ditemukan secara nyata dapat membedakan antara yang sukses dengan yang biasa saja di tempat kerja.

Bangun (2012:11) mengemukakan bahwa motivasi kerja merupakan dorongan kepada karyawan untuk melaksanakan pekerjaan, dengan motivasi kerja, karyawan dapat melaksanakan pekerjaannya dengan baik. Berbagai metode motivasi dapat dipilih untuk dilaksanakan, tetapi hal yang paling penting disini adalah melakukan dorongan kepada karyawan untuk menumbuhkan semangat kerja dalam mencapai tujuan organisasi.

Hasil dari wawancara yang dilakukan dengan Bapak Fikri Hudori pegawai KPKNL Palu mengatakan setiap pagi KPKNL Palu mengadakan pertemuan untuk semua pegawai, membahas apa yang akan dilakukan atau dikerjakan pada hari ini, hal ini bertujuan untuk memotivasi pegawai. Akan tetapi motivasi kerja sangat erat kaitannya dengan adanya beberapa kebutuhan yang berbeda-beda pada masing-masing pegawai. Kebutuhan dalam mencapai kesuksesan adalah kemampuan untuk mencapai standar perusahaan yang telah ditentukan juga perjuangan karyawan untuk menuju keberhasilan. Setiap pegawai menginginkan karirnya meningkat, salah satunya adalah dengan membuat pimpinan terkesan. Namun untuk menimbulkan kesan yang dihasilkan tersebut bukan berarti seorang pegawai harus mengambil alih pekerjaan pegawai lainnya, namun hal ini yang terjadi di KPKNL Palu. Menuju keberhasilannya, pegawai KPKNL Palu melakukan pekerjaannya dengan sungguh-sungguh dan jika ada pekerjaan yang belum selesai dikerjakan oleh pegawai lainnya siap untuk membantu untuk menyelesaikan pekerjaanya.

Kualitas pelayanan atau service quality merupakan kunci utama dari pelayanan publik yang diberikan kepada masyarakat. Kualitas pelayanan merupakan tingkat keunggulan yang diharapkan dan pengendalian atas tingkat keunggulan tersebut untuk memenuhi keinginan pelanggan (Wyckof dalam Prianggono dan Manupputy, 2010:60). Service quality yang baik dan prima, akan menciptakan suatu persepsi yang baik dari masyarakat terhadap pelayanan yang diberikan. Persepsi baik masyarakat yang timbul kemudian tumbuh menjadi perasaan puas dari masyarakat karena telah memenuhi harapan yang diinginkan oleh masyarakat tersebut.

Disamping itu Reliability (kehandalan) merupakan kemampuan untuk melaksanakan jasa yang dijanjikan dengan terpercaya dan akurat, pada KPKNL Palu tata aturan susunan cara kerja masih terbilang sangat lambat, hal ini ditunjukkan dari proses rekonsiliasi yang bisa dikatakan rumit, sehingga proses penyelenggaraan pelayanannya menjadi panjang, berbelit-belit dan waktu yang digunakan cukup lama. Adapun tujuan yang ingin dicapai dalam penelitian ini:

1. Untuk mengetahui dan menguji Kompetensi dan Motivasi Kerja berpengaruh simultan terhadap

Kualitas Layanan Pada Kantor Layanan Kekayaan Negara dan Lelang Palu.

2. Untuk mengetahui dan menguji Kompetensi berpengaruh parsial terhadap Kualitas layanan Pada

Kantor Pelyanan Kekayaan Negara dan Lelang Palu.

3. Untuk mengetahui dan menguji Motivasi Kerja berpengaruh parsial terhadap Kualitas layanan Pada Kantor Pelayanan kekayaan dan Lelang Palu. 


\section{KAJIAN LITERATUR DAN PENGEMBANGAN HIPOTESIS}

\section{Pengertian Kompetensi}

Wibowo (2007:271) mengemukakan bahwa kompetensi adalah suatu kemampuan untuk melaksanakan atau melakukan suatu pekerjaan atau tugas yang dilandasi atas keterampilan dan pengetahuan serta didukung oleh sikap kerja yang dituntut oleh pekerjaan tersebut. Kompetensi menunjukkan keterampilan atau pengetahuan yang dicirikan oleh profesionalisme dalam suatu bidang tertentu sebagai sesuatu yang terpenting, sebagai unggulan bidang tersebut. Kompetensi sebagai kemampuan seseorang untuk menghasilkan pada tingkat yang memuaskan ditempat kerja, termasuk diantaranya kemampuan seseorang untuk menstransfer dan mengaplikasikan keterampilan dan pengetahuan tersebut dalam situasi yang baru dan meningkatkan manfaat yang disepakati.

\section{Dimensi Kompetensi}

Sementara itu Veitzal Rivai dalam Sriwidodo (2010:50) mengemukakan bahwa:Kemampuan seseorang merujuk ke suatu kapasitas individu untuk mengerjakan berbagai tugas dalam suatu pekerjaan dan seluruh kemampuan seorang individu pada hakekatnya tersusun dalam dua perangkat faktor, yaitu:

1. Kemampuan Intelektual

Kemampuan intelektual seseorang berhubungan dengan tingkat IQ atau menyangkut kecerdasan dalam hal pengetahuan. Selain berhubungan dengan IQ (Intellegence Quotient) juga berhubungan dengan EQ (Emotional Quotient) atau kecerdasan emosional.

2. Kemampuan Fisik

Kemampuan fisik memiliki makna penting khusus untuk melakukan pekerjaan yang kurang menuntut keterampilan. Kompetensi yang diperlukan seseorang dalam suatu pekerjaan dapat diukur dari sifat/karakteristik bisa dilihat dari pikiran, sikap, dan perilaku.

\section{Pengertian Motivasi Kerja}

Motivasi sebagai proses yang menyebabkan intensitas (intestity), arah (direction), dan usaha terusmenerus (persistence) individu menuju pencapaian tujuan (Robbins dalam Wibowo 2007:322). Intensitas menunjukkan seberapa keras seseorang berusaha. Tetapi intensitas tidak mungkin mengarah pada hasil kinerja yang baik, kecuali usaha dilakukan dalam arah yang menguntungkan organisasi. Karenanya harus dipertimbangkan kualitas maupun intensitasnya. Motivasi mempunyai dimensi usaha terus menerus.

Greenberg dan Baron dalam Wibowo (2007:322) berpendapat bahwa motivasi merupakan seraingkaian proses yang membangkitkan (arouse), mengarahkan (direct), dan menjaga (maintain) perilaku manusia menuju pada pencapaian tujuan. Membangkitkan berkaitan dengan dorongan atau energi di belakang tindakan. Motivasi juga berkepentingan dengan pilihan yang dilakukan orang dan arah perilaku mereka. Sedang perilaku menjaga atau memelihara berapa lama orang akan terus berusaha untuk mencapai tujuan.

Beberapa pendapat di atas dapat disimpulkan bahwa motivasi merupakan dorongan terhadap seraingkaian proses perilaku manusia pada pencapaian tujuan. Sedangkan elemen yang terkandung dalam motivasi meliputi unsur membangkitkan, mengarahkan, menjaga, menunjukkan intensitas, bersifat terus-menerus dan adanya tujuan.

\section{Dimensi Motivasi Kerja}

McClelland dalam Mulyadi (2010:100) menyatakan bahwa pemahaman tentang motivasi akan semakin mendalam apabila di sadari bahwa setiap orang mempunyai tiga jenis kebutuhan yaitu:

1. Kebutuhan dalam mencapai kesuksesan (Need for Achievement); kemampuan untuk mencapai hubungan kepada standar perusahaan yang telah ditentukan juga perjuangan karyawan untuk menuju keberhasilan.

2. Kebutuhan dalam kekuasaan atas otoritas kerja (Need for Power); kebutuhan untuk membuat orang berperilaku dalam keadaan yang wajar dan bijaksana di dalam tugasnya masing-masing. 
3. Kebutuhan untuk berafilisiasi (Need for affiliation); hasrat untuk bersahabat dan mengenal lebih dekat rekan kerja atau para karyawan di dalam organisasi.

\section{Pengertian Kualitas Layanan}

Zeithaml dalam Laksana (2008:88) kualitas pelayanan dapat didefinisikan sebagai "The extent of discrepancy between customers expectations desires and their perception", dari pernyataan tersebut dikemukakan bahwa kualitas pelayanan yang diterima konsumen dinyatakan besarnya perbedaan antara harapan atau keinginan konsumen dengan tingkat persepsi mereka.

Lovelock dalam Laksana (2008:88) mengemkakan "Quality is degree of exellent intended, and the control of variability in achieving that excellent, in meeting the customers requirements". Dikatakan bahwa kualitas adalah tingkat mutu yang diharapkan, dan pengendalian keragaman dalam mencapai mutu tersebut untuk memenuhi kebutuhan konsumen. Untuk dapat memberikan kualitas pelayanan yang baik maka perlu dibina hubungan yang erat antar perusahaan, dalam hal ini adalah karyawan dengan pemakai jasa tersebut. Demikian dapat disimpulkan bahwa kualitas merupakan faktor kunci sukses bagi suatu organisasi atau perusahaan.

\section{Dimensi Kualitas Layanan}

Fitzsimmons dalam Prianggono dan Manupputy (2011:62) terdapat lima dimensi penentu kualitas yang disajikan berdasarkan nilai pentingnya menurut pelanggan, yaitu :

1. Reliability (kehandalan), kemampuan untuk melaksanakan jasa yang dijanjikan dengan terpercaya dan akurat.

2. Responsiveness (daya tanggap), kemauan untuk membantu pelanggan dan memberikan jasa dengan cepat.

3. Assurance (jaminan), pengetahuan dan kesopanan karyawan dan kemampuan mereka untuk menimbulkan kepercayaan dan keyakinan.

4. Empathy (empati), kesediaan untuk peduli, member perhatian pribadi kepada pelanggan.

5. Tangibles (bukti langsung), penampilan fisik (contoh: gedung, gudang, dan lain-lain), peralatan, personil, dan materi komunikasi.

\section{Kerangka Pemikiran}

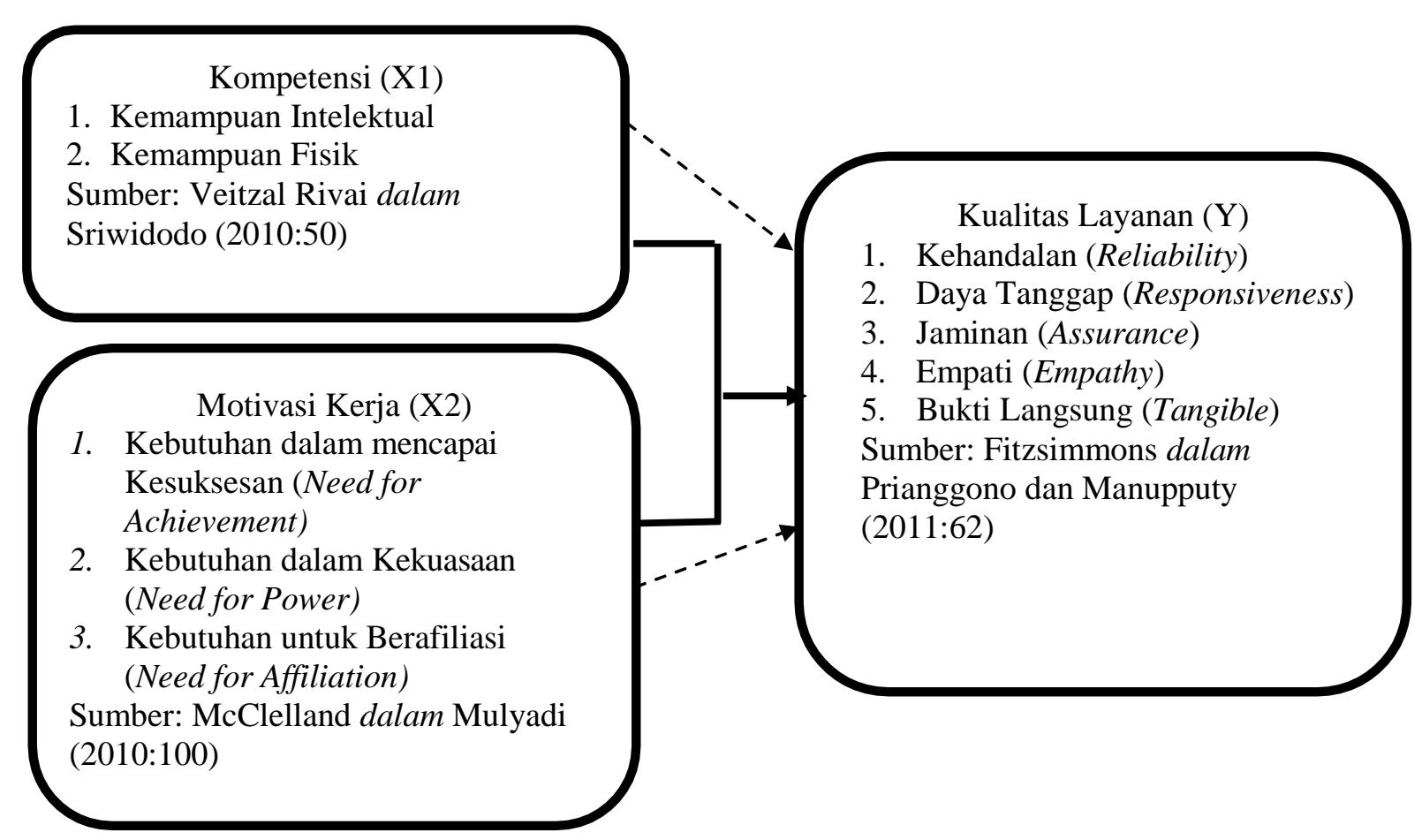

Gambar 1 Kerangka Pemikiran 


\section{Hipotesis}

1. Kompetensi dan Motivasi Kerja berpengaruh simultan terhadap Kualitas Layanan pada Kantor Pelayanan Kekayaan Negara dan Lelang Palu.

2. Kompetensi berpengaruh parsial terhadap Kualitas Layanan pada Kantor Pelayanan Kekayaan Negara dan Lelang Palu.

3. Motivasi berpengaruh parsial terhadap Kualitas Layanan pada Kantor Pelayanan Kekayaan Negara dan Lelang Palu.

\section{METODE PENELITIAN}

Penelitian ini termasuk kedalam jenis kausalitas karena penelitian ini bersifat menunjukkan hubungan antar dua variabel atau lebih, atau bagaimana satu variabel memengaruhi variabel lainnya (Umar, 2003:87). Selanjutnya dicari seberapa besar pengaruh variabel independen kompetensi, dan motivasi kerja terhadap variabel dependen kualitas layanan pada KPKNL Palu (Sugiyono, 2014:18). Menurut jenis datanya, penelitian ini merupakan penelitian kuantitatif karena data yang yang disajikan dalam penelitian ini merupakan data dalam bentuk angka.

Teknik pengambilan sampel dalam penelitian ini berdasarkan teknik simple random sampling. Sugiarto, et al, (2003:46) mengemukakan: Simple random sampling adalah metode yang digunakan untuk memilih sampel dari populasi dengan cara sedemikian rupa sehingga setiap anggota populasi mempunyai peluang yang sama besar untuk diambil sebagai sampel. Pengambilan sampel ini dilakukan dengan cara undian, dengan menggunakan nomor-nomor yang mewakili satker/institusi yang menjadi populasi, kemudian dikocok/diguncang, nomor-nomor yang mewakili satker yang keluar dari kocokan tersebut adalah unit sampel yang akan dijadikan responden (orang atau pegawai yang mewakili dalam 1 satker) dan yang telah melakukan pelaporan rekonsiliasi atau konsultasi ke KPKNL Palu sebanyak 4 sampai 6 kali kunjungan. Cara membedakan jika terdapat satker yang sama dapat dilihat pada nama dan kode satker. Adapun rumus teknik pengambilan sampel secara proportional random sampling yaitu sebagai berikut:

$\mathrm{n}=\frac{N}{1+N(e)^{2}}$

Atas dasar rumus diatas, maka dapat dihitung jumlah sampel penelitian sebagai berikut:

$\mathrm{n}=\frac{262}{1+262(0,1)^{2}}$

$\mathrm{n}=72,37$ sampel, dibulatkan menjadi 72 sampel.

Teknik pengumpulan data dalam Penelitian ini adalah:

1. Observasi, yaitu observasi merupakan cara pengumpulan data melalui proses pencatatan perilaku subjek (orang), objek (benda), atau kejadian yang sistematik tanpa adanya pertanyaan atau komunikasi dengan individu-individu yang diteliti, Sanusi (2011:111).

2. Wawancara, adalah wawancara dapat dilakukan secara terstruktur maupun tidak tersruktur dan dapat dilakukan melalui tatap muka (face to face) maupun dengan menggunakan telepon, Sugiyono (2014:194).

3. Dokumentasi, merupakan dokumentasi biasanya dilakukan untuk mengumpulkan data sekunder dari berbagai sumber, baik secara pribadi maupun kelembagaan, Sanusi (2011:114).

Analisis data menggunakan regresi linear berganda. Regresi berganda digunakan untuk menaksir bagaimana keadaan (naik turun) variabel dependen, bila dua atau lebih variabel dependen sebagai faktor predictor dimanipulasi (dinaikturunkan nilainya) (Sugiyono, 2012:277). Bila dijabarkan secara matematis, maka bentuk persamaan dari regresi linear berganda ialah sebagai berikut:

$Y=a+b_{1} X_{1}+b_{2} X_{2}+e$ 
Dimana:

Y

$\mathrm{X}(1,2,3 \ldots)$

$\mathrm{a}$

b $(1,2,3 \ldots)$

e
$=$ Variabel Terikat (Independen)

$=$ Variabel Bebas (Independen)

$=$ Nilai Konstanta

$=$ Nilai Koefisien Regresi

$=$ Error (Residual)

\section{HASIL DAN PEMBAHASAN}

Tabel.1 Hasil Regresi Linear Berganda

\begin{tabular}{lllll}
\hline \multicolumn{5}{c}{ Dependen Variabel Y = Kinerja } \\
\multicolumn{1}{c}{ Variabel } & Koefisien Regresi & Standar Error & $\mathbf{t}$ & Sig \\
\hline Constanta & 0,068 & 0,168 & 0,406 & 0,686 \\
\hline $\mathrm{X}_{1}=$ Kompetensi & 0,152 & 0,113 & 1,348 & $0,182>0,05$ \\
\hline $\mathrm{X}_{2}=$ Disiplin Kerja & 0,839 & 0,107 & 7,811 & $0,000<0,05$ \\
\hline $\mathrm{R}$ & $=0,951$ & & & \\
\hline R-Square & $=0,904$ & & & \\
\hline F Statistik & $=323,168$ & & \\
\hline Sig. F & $=0,000<0,05$ & & \\
\hline
\end{tabular}

Berdasarkan nilai dari Tabel.1 diatas, maka persamaan regresi linear berganda dapat dirumuskan sebagai berikut:

$\mathrm{Y}=\mathbf{0 , 0 6 8}+\mathbf{0 , 1 5 2 X 1}+\mathbf{0 , 8 3 9} \mathrm{X}_{2}$

(4)

Adapun penjelasan bentuk persamaan tersebut, adalah sebagai berikut:

1. Nilai konstanta sebesar 0,068 nilai ini menunjukkan bahwa apabila variabel independen kompetensi $\left(\mathrm{X}_{1}\right)$ motivasi kerja $\left(\mathrm{X}_{2}\right)$ berpengaruh positif dan signifikan terhadap variabel dependen Kualitas Layanan (Y). Berarti jika kompetensi dan motivasi kerja tidak berubah/konstan maka kualitas layanan di Kantor Pelayanan Kekayaan Negara dan Lelang (KPKNL) Palu akan meningkat sebesar 0,068.

2. Koefisien regresi variabel Kompetensi $\left(\mathrm{X}_{1}\right)$ sebesar 0,152 ini berarti terjadi pengaruh positif antara kompetensi dan kualitas layanan, semakin tinggi kompetensi pegawai dalam bekerja pada KPKNL Palu maka kualitas layanan akan meningkat sebesar 15,2\%. Penelitian ini pada variabel kompetensi berpengaruh tidak signifikan terhadap kualitas layanan pada KPKNL Palu, karena nilai sig 0,182 > 0,05 .

3. Koefisien regresi variabel Motivasi Kerja $\left(\mathrm{X}_{2}\right)$ terdapat pengaruh signifikan dan bernilai positif yaitu sebesar 0,839. Hal ini menyatakan bahwa setiap peningkatan motivasi kerja sebesar 1 satuan, maka tingkat kualitas layanan pada KPKNL Palu akan naik sebesar 0,839 .

4. Nilai koefisien korelasi (Multi R) sebesar 0,951 menunjukkan bahwa hubungan antara variabel independen terhadap variabel dependen sebesar $95,1 \%$ berkorelasi sangat kuat, maka dapat disimpulkan bahwa nilai tersebut menunjukkan hubungan yang kuat atara variasi variabel keeratan hubungan variabel independen (Kompetensi, Motivasi Kerja) dengan variabel dependen (Kulitas Layanan).

\section{Uji F}

Uji F bertujuan untuk mengetahui apakah variabel independen yakni kompetensi dan motivasi kerja yang diteliti memiliki pengaruh secara serempak terhadap variabel dependen yakni kualitas layanan pada Kantor Pelayanan Kekayaan Negara dan Lelang di Kota Palu, mempunyai nilai signifikansi F = 
$0,000<0,05$. Kesimpulannya adalah variabel bebas secara bersama-sama (serempak) berpengaruh signifikan terhadap variabel terikat, artinya bahwa variabel kompetensi dan motivasi kerja secara bersama-sama (serempak) berpengaruh positif dan signifikan terhadap variabel kualitas layanan pada Kantor Pelayanan Kekayaan Negara dan Lelang di Kota Palu. Hipotesis yang menyatakan bahwa kompetensi dan motivasi kerja berpengaruh positif dan signifikan terhadap kualitas layanan pada Kantor Pelayanan Kekayaan Negara dan Lelang di Kota Palu berdasarkan uji-F hasilnya terbukti.

\section{Uji t}

Uji t dilakukan untuk menguji apakah sebuah variabel independen (Kompetensi dan Motivasi Kerja) benar-benar memberikan kontribusi terhadap variabel dependen (Kulitas Layanan) pada Kantor Pelayanan Kekayaan Negara dan Lelang di Kota Palu. Adapun hasil uji hipotesis secara parsial dapat dilihat sebagai sebagai berikut:

1. Variabel Kompetensi

Variabel kompetensi memiliki tingkat signifikansi t sig. $(0,182)>\alpha(0,05)$. Hal ini menunjukkan bahwa hipotesis yang menyatakan "Kompetensi berpengaruh secara parsial terhadap Kualitas Layanan pada Kantor Pelayanan Kekayaan Negara dan Lelang (KPKNL) Palu” tidak terbukti atau bahwa ( $\mathrm{H}_{0}$ diterima dan $\mathrm{H}_{\mathrm{a}}$ ditolak).

2. Variabel Motivasi Kerja

Variabel motivasi kerja memiliki tingkat signifikansi t sig. $(0,00)<\alpha(0,05)$. Hal ini menunjukkan bahwa hipotesis yang menyatakan "Motivasi Kerja berpengaruh secara parsial terhadap Kualitas Layanan pada Kantor Pelayanan Kekayaan Negara dan Lelang (KPKNL) Palu” terbukti atau bahwa ( $\mathrm{H}_{\mathrm{o}}$ ditolak dan $\mathrm{H}_{\mathrm{a}}$ diterima).

\section{PEMBAHASAN}

\section{Pengaruh Kompetensi dan Motivasi Kerja terhadap Kualitas layanan Pegawai KPKNL Palu}

Berdasarkan hasil uji F yang dilakukan, menunjukkan hasil bahwa kompetensi dan motivasi kerja secara serempak berpengaruh signifikan terhadap kualitas layanan. Hasil ini memberikan arti hipotesis pertama yang menyatakan kompetensi dan motivasi kerja secara serempak berpengaruh terhadap kualitas layanan pada Kantor Pelayanan Kekayaan Negara dan Lelang (KPKNL) Palu dan diterima.

Variabel kompetensi dan motivasi kerja merupakan faktor yang memengaruhi kualitas layanan pada KPKNL Palu, dalam hal kompetensi memberikan pelayanan yang baik adalah sikap pegawai yang dapat memenuhi kebutuhan pengunjung (orang yang mewakili satker) dan dapat menyelesaikan jika terjadi kendala pada saat melakukan pelayanan. Hal ini menunjukkan bahwa dari segi kemampuan intelektual pegawai KPKNL Palu melaksanakan pekerjaan atau tugasnya dengan baik, seperti ditunjukkan dari sikap pegawai yang mampu memberikan penjelasan terkait rekonsiliasi, mampu membantu satker untuk memperbaharui/menginstal aplikasi SIMAN/SIMAK dan memberikan informasi yang dibutuhkan oleh orang yang mewakili satker. Sedangkan motivasi kerja memengaruhi sikap pegawai untuk saling berinteraksi dengan pengunjung (orang yang mewakili satker) serta dengan pegawai lainnya dan selalu bertanggung jawab dengan pekerjaannya. Dimensi dari segi kebutuhan akan afiliasi, pegawai KPKNL Palu melaksanakan pekerjaan dengan baik ditunjukkan dari sikap pegawai dan pengguna jasa (satker) saling menghargai contohnya sikap pegawai KPKNL Palu menyapa satker yang baru datang dengan sikap dan tutur bahasa yang baik dan sopan.

Berdasarkan hasil perhitungan regresi linear memperoleh bahwa variabel kompetensi dan motivasi kerja terdapat pengaruh positif dan signifikan terhadap kualitas layanan yang artinya apabila kompetensi dan motivasi kerja meningkat, maka kualitas layanan pada KPKNL Palu akan meningkat. Untuk meningkatkan kompetensi pegawai diKPKNL Palu menggunakan bidang akademik, pemecahan 
masalah, berpikir kritis dan mengoperasikan komputer. Sedangkan untuk meningkatkan motivasi kerja pegawai diKPKNL Palu, dengan membangkitkan dan mengarahkan pegawai, yang setiap harinya dilaksanakan pertemuan untuk setiap pegawai. Hal ini untuk memotivasi pegawai serta menumbuhkan rasa semangat dalam bekerja.

Penjelasan tersebut dapat dikatakan bahwa kedua variabel independen yaitu kompetensi dan motivasi kerja memiliki pengaruh terhadap peningkatan kualitas layanan pegawai KPKNL Palu. Hasil penelitian ini juga sama dengan penelitian yang telah dilakukan oleh Mukaromah (2016) yang menyatakan bahwa variabel motivasi kerja dan kemampuan kerja secara bersama-sama berpengaruh signifikan terhadap kualitas pelayanan karyawan Bank Rakyat Indonesia Balikpapan.

\section{Pengaruh Kompetensi terhadap Kualitas Layanan Pegawai KPKNL Palu}

Berdasarkan hasil perhitungan regresi linear memperoleh bahwa variabel kompetensi terdapat pengaruh positif terhadap variabel kualitas layanan sebesar 0,152 yang artinya apabila kompetensi meningkat sebesar 15,2\% maka kualitas layanan akan meningkat sebesar 15,2\%. Untuk meningkatkan kompetensi pegawai diKPKNL Palu menggunakan bidang akademik, pemecahan masalah, berpikir kritis dan mengoperasikan komputer. Namun pada penelitian ini variabel kompetensi dinyatakan tidak signifikan terhadap kualitas layanan pada KPKNL Palu, karena nilai sig 0,182 > 0,05, maka sampel yang berjumlah 72 satker tidak dapat mewakili atau digeneralisasikan pada populasi yang sebesar 262 satker.

Dimensi kemampuan intelektual yang baik ditunjukkan dengan sikap pegawai yang pada saat melakukan palayanan dapat mengontrol emosinya, misalnya pegawai bersikap ramah atau tidak mudah marah pada saat melakukan pelayanan dan membantu dengan sabar dalam mengarahkan satker jika terjadi kesalahan pada saat melakukan rekonsiliasi. Kemampuan intelektual merupakan kemampuan yang dibutuhkan untuk melakukan berbagai aktivitas pekerjaan seperti mental dan berfikir serta memecahkan masalah. Hal ini yang selalu diperhatikan dan dilaksankan oleh pegawai KPKNL Palu.

Wibowo (2007:271) mengemukakan bahwa kompetensi adalah suatu kemampuan untuk melaksanakan atau melakukan suatu pekerjaan atau tugas yang dilandasi atas keterampilan dan pengetahuan serta didukung oleh sikap kerja yang dituntut oleh pekerjaan tersebut. Namun kompetensi yang dimiliki oleh pegawai KPKNL Palu untuk melakukan rekonsiliasi adalah kemampuan dalam mengopersionalkan komputer dan mampu menggunakan aplikasi SIMAK/SIMAN, bukan dilihat dari kemampuan fisik dan kemampuan intelektualnya. Hal ini memberikan arti dimata pelanggan atau satker kompetensi tidak berpengaruh secara signifikan terhadap kualitas layanan pada KPKNL Palu.

Hasil dari wawancara yang dilakukan dengan salah satu pegawai KPKNL Palu yaitu bapak Nanang Setiyono mengatakan bahwa pegawai dalam melakukan pelayanan rekonsiliasi tidak membutuhkan kemampuan yang khusus. Hal ini dikarenakan rekonsiliasi merupakan bagian terkecil dari penatausahaan yang dimana seluruh kegiatannya sudah menggunakan sistem aplikasi.

Penjelasan tersebut dapat dikatakan bahwa dalam memberikan pelayanan rekonsiliasi dapat dilakukan oleh orang yang tidak mempunyai kemampuan khusus seperti kemampuan intelektual dan kemampuan fisik, sehingga di KPKNL Palu pada bagian pelayanan rekonsiliasi bukan hanya pegawai tetap dan pegawai honorer. Tetapi, mahasiswa dan siswa yang melakukan PKL (Praktek Kerja Lapangan) atau magang di KPKNL Palu juga melakukan pelayanan rekonsiliasi. Hal ini menunjukkan bahwa adanya pegawai yang kurang terlatih dan belum mahir dalam mengoperasionalkan komputer dan aplikasi SIMAK/SIMAN, tetapi hal ini tidak menyebabkan/berdampak pada kualitas pelayanan pegawai. Hal ini dikarenakan dalam mengoperasionalkan komputer tidak memerlukan kemampuan khusus orang lain yang bukan pegawai juga dapat mengoperasionalkan komputer asalkan mereka belajar tentang komputer. Demikian dapat dikatakan bahwa kompetensi pegawai tidak berpengaruh signifikan terhadap kualitas layanan pada KPKNL Palu. 


\section{Pengaruh Motivasi Kerja terhadap Kualitas Layanan Pegawai KPKNL Palu}

Berdasarkan hasil perhitungan regresi linear memperoleh bahwa variabel motivasi kerja terdapat pengaruh positif terhadap kualitas layanan sebesar 0,839 yang artinya apabila motivasi kerja meningkat sebesar $83,9 \%$ maka kualitas layanan akan meningkat sebesar $83,9 \%$. Pada penelitian ini variabel motivasi kerja mempunyai pengaruh signifikan karena nilai sig $0,00<0,05$, nilai signifikan menunjukkan bahwa motivasi kerja mempunyai peranan yang penting dalam meningkatkan kualitas layanan. Untuk meningkatkan motivasi kerja pegawai diKPKNL Palu, dengan membangkitkan dan mengarahkan pegawai, yang setiap harinya dilaksanakan pertemuan untuk setiap pegawai. Hal ini untuk memotivasi pegawai serta menumbuhkan rasa semangat dalam bekerja.

Motivasi kerja yang sangat dominan adalah dimensi kebutuhan akan afiliasi yang ditunjukkan dari sikap pegawai yang memiliki komunikasi yang baik dengan pengguna jasa (satker), pegawai dan satker saling menghargai, dan interaksi dalam pekerjaan adalah salah satu pendorong guna untuk melancarkan pekerjaannya. Pegawai melayani dengan baik, menanggapi jika adanya keluhan-keluhan dari pengunjung, dan menghubungi jika adanya kesalahan atau kurangnya informasi dari pengunjung dan pegawai jadi dapat katakan bahwa hubungan baik terjalin dan memiliki komunikasi yang baik antar pegawai dan pengunjung (orang yang mewailiki satker), contohnya pegawai menghubungi pihak wakil satker jika terjadi kesalahan dalam rekonsiliasi. Kesalahan yang paling banyak terjadi adalah adanya selilisih antara saldo awal dan saldo akhir.

Komunikasi yang baik antara pegawai dan satker dapat mempermudah pada saat melakukan pelayanan. Pegawai KPKNL Palu dalam melakukan pekerjaannya khususnya dibagian pelayanan rekonsiliasi memberikan pelayanan yang baik seperti bersikap ramah dan sopan. Hal ini guna menjaga hubungan baik antara pegawai dan satker. Namun hubungan baik bukan hanya terjalin pada pegawai dan satker tetapi antar pegawai KPKNL Palu juga mempunyai hubungan yang baik, dalam hal ini ditunjukkan dari sikap pegawai yang selalu hadir pada saat apel pagi sebelum melakukan tugasnya masing-masing. Hal ini guna mempererat hubungan baik serta memberikan motivasi antar pegawai.

Menurut Greenberg dan Baron dalam Wibowo (2007:322) bahwa motivasi merupakan seraingkaian proses yang membangkitkan (arouse), mengarahkan (direct), dan menjaga (maintain) perilaku manusia menuju pada pencapaian tujuan. Membangkitkan berkaitan dengan dorongan atau energi di belakang tindakan. Motivasi juga berkepentingan dengan pilihan yang dilakukan orang dan arah perilaku mereka. Sedang perilaku menjaga atau memelihara berapa lama orang akan terus berusaha untuk mencapai tujuan. Hasil penelitian ini juga sama dengan penelitian yang telah dilakukan oleh Enceng dan Yuli Tirtariandi (2012) dengan hasil penelitian bahwa variabel motivasi kerja secara parsial berpengaruh signifikan terhadap kualitas pelayanan di Kantor Kecamatan Jatinangor Kabupaten Sumedang.

\section{KESIMPULAN DAN SARAN}

\section{Kesimpulan}

Berdasarkan hasil pembahasan penelitian yang telah dikemukakan diatas, maka penulis mengambil beberapa kesimpulan dari hasil penelitian ini sebagai berikut: Kompetensi dan motivasi kerja berpengaruh positif dan signifikan terhadap kualitas layanan pada Kantor Pelayanan Kekayaan Negara dan Lelang di Kota Palu. Kompetensi berpengaruh positif dan tidak signifikan terhadap kualitas layanan pada Kantor Pelayanan Kekayaan Negara dan Lelang di Kota Palu. Motivasi berpengaruh positif dan signifikan terhadap kualitas layanan pada Kantor Pelayanan Kekayaan Negara dan Lelang di Kota Palu.

\section{Saran-saran}

Berdasarkan pada penelitian yang telah dilakukan dan hasil kesimpulan yang diperoleh, maka saran yang diajukan penelitian dalam penelitian ini adalah sebagai berikut: 
1. Untuk variabel kompetensi, diharapkan mampu untuk meningkatkan dan memaksimalkan kompetensi pegawai Kantor Pelayanan Kekayaan Negara dan Lelang Palu, dalam hal ini pegawai harus mampu menyelesaikan urusan pelayanan sesuai dengan waktu yang telah ditentukan dan pegawai harus meningkatkan kepercayaan dirinya pada saat memberikan pelayanan.

2. Untuk variabel motivasi kerja diharapkan mampu untuk meningkatkan motivasi kerja para pegawai Kantor Pelayanan Kekayaan Negara dan Lelang (KPKNL) Palu, dalam hal ini pegawai harus meningkatkan dalam menyelesaikan pekerjaannya sendiri tanpa meminta bantuan pegawai lainnya dan pegawai harus lebih mementingkan pekerjaannya dari pada kepentingan pribadi.

3. Untuk variabel kualitas layanan diarapkan mampu untuk meningkatkan kualitas layanan pada Kantor Pelayanan Kekayaan Negara dan Lelang (KPKNL) Palu, dalam hal ini pegawai harus meningkatkan dalam ketepatan waktu seperti selalu cepat dan merespon keinginan satker dan meningkatkan empati seperti lebih memberikan perhatian kepada satker pada saat pelayanan.

4. Bagi Peneliti Selanjutnya

Bagi peneliti selanjutnya yang ingin meneliti atau melanjutkan penelitian ini, disarankan untuk meneruskan atau mengembangkan penelitian ini dengan menambah variabel yang lain dan yang belum terungkap sebelumnya yang dapat mempengaruhi kualitas layanan pada Kantor Pelayanan Kekayaan Negara dan Lelang (KPKNL) Palu.

\section{REFERENSI}

Bangun, Wilson, 2012. Manajemen Sumber Daya Manusia, Jakarta: Erlangga.

Enceng dan Yuli Tirtariandi, 2012. Pengaruh Motivasi Kerja Dan Kinerja Aparatur Pemerintah Kecamatan Terhadap Kualitas Pelayanan Masyarakat (Studi Di Kantor Kecamatan Jatinangor Kabupaten Sumedang). Jurnal Ilmiah Administrasi Publik dan Pembangunan, Vol.3, No.1. hal.405-406.

Laksana, 2008. Manajemen Pemasaran, Yogyakarta: Graha Ilmu.

Mukaromah, 2016. Pengaruh Motivasi Kerja dan Kemampuan Kerja Terhadap Mutu Pelayanan Karyawan Bank Rakyat Indonesia BalikPapan. PSIKOBORNEO, Volume 4, Nomor 2, hal.268272.

Mulyadi, Hari, 2010. Pengaruh Motivasi Dan Kompetensi Kerja Terhadap Produktivitas Kerja Karyawan Pada PT. Galamedia Bandung Perkasa. Manajerial, Vol. 9, No. 17, hal.104.

Prianggono, Jarot Dan Manupputy, 2011. Pengaruh Kualitas Pelayanan Terhadap Kepuasan Wajib Pajak Dalam Penerbitan Surat Tanda Nomor Kendaraan Di Samsat Balikpapan, Jurnal Makna, Volume 1, Nomor 2, hal. 62.

Sanusi, Anwar, 2011. Metode Penelitian Bisnis, Jakarta: Salemba Empat.

Sartika, Amwiarni, 2015. Pegaruh Kompetensi, Disiplin Kerja, Dan Pengalaman Kerja Terhadap Kinerja Pegawai Dinas Pendapatan Pengelolaan Keuangan Dan Aset Daerah Kota Palu. E-Jurnal Katalogis, Volume 3, Nomor 1, hal.55-57.

Sriwidodo, Untung, 2010. Pengaruh Kompetensi, Motivasi, komunikasi Dan Kesejahteraan Terhadap Kinerja Pegawai Dinas Pendidikan. Jurnal Manajemen Sumber daya Manusia, Vol. 4, No. 1, hal. 49-50.

Sugiarto, Siagian, Sunaryanto, dan Oetomo, 2003. Teknik Sampling, Jakarta: PT. Gramedia Pustaka Utama.

Sugiyono, 2012. Metode Penelitian Manajemen. Bandung: Alfabeta.

Sugiyono, 2014. Metode Penelitian Kuantitatif, Kualitatif dan R\&D, Bandung: Alfabeta.

Sutrisno, Edi, 2009. Manajemen Sumber Daya Manusia, Jakarta: Kencana Prenada Media Group. Umar, Husen, 2003. Metodologi Penelitian: Aplikasi dalam Pemasaran. Jakarta: PT. Gramedia

Pustaka Utama.

Wibowo, 2007. Manajemen Kinerja, Jakarta: PT. RajaGrafindo Persada. 